\title{
TEORETIČNA IN TERMINOLOŠKA IZHODIŠČA IZSELJENSTVA TER POZNAVANJE TEMATIKE IZSELJENSTVA MED SLOVENSKIMI UČENCI IN DIJAKI
}

\section{Mojca Ilc Klun}

Oddelek za geografijo, Filozofska fakulteta Univerze v Ljubljani

Aškerčeva 2, SI-1000 Ljubljana

e-mail: mojca.ilc@ff.uni-lj.si

Izvirni znanstveni članek

COBISS 1.01

DOI: 10.4312/dela.41.9.165-181

\section{Izvleček}

Prvi del prispevka obravnava osnovna teoretična in terminološka izhodišča izseljenstva, med drugim teorije migracij in teoretični oris nekaterih pojmov, vezanih na migracije. V drugem delu se osredotoča na prikaz ključnih ugotovitev empirične raziskave med 687 učenci in dijaki devetih slovenskih šol, ki kažejo poznavanje terminologije izseljenstva med mladimi.

Ključne besede: izseljenstvo, terminologija, didaktika geografije, učenci in dijaki

\section{THEORETICAL ASPECTS OF EMIGRATION AND KNOWLEDGE OF EMIGRATION TERMINOLOGY AMONG SLOVENIAN PUPILS}

\begin{abstract}
The first part of the paper deals with basic theoretical and terminological aspects of emigration, including migration theories and theoretical discourse of migration terminology. The second part is focused on key findings of empirical research among 687 Slovenian pupils of nine schools, which show the knowledge of emigration terminology among the youth.
\end{abstract}

Key words: emigration, terminology, didactics of geography, pupils and students 


\section{UVOD}

Področje raziskovanja migracij in z njimi povezanega slovenskega izseljenstva, diaspore, je izrazito interdisciplinarno in multidisciplinarno, saj se z naslovno tematiko danes ukvarjajo različne znanstvene vede, tudi geografija. Selitveni tokovi imajo že dolgo zgodovino, od razseljevanja afriškega človeka pred nekaj milijoni let, pa vse do sodobnih migracij, kot ene izmed posledic oziroma značilnosti globalizacijske družbe 21. st. Projekcije kažejo, da bodo migracijski tokovi v prihodnosti neprimerljivo večji, obsežnejši in bolj globalni kot v preteklosti (Kovač, 2003). Se jim bomo v vse večji meri pridružili tudi Slovenci?

Slovenski narod je eden izmed manjših evropskih narodov, a ga kljub temu uvrščamo med narode z zelo številčno diasporo. Po nekaterih podatkih naj bi izven meja Slovenije živelo okoli 500.000 ljudi slovenskega etničnega izvora, kar naj bi predstavljalo 'peto četrtino’ vseh današnjih državljanov Republike Slovenije (Geografski atlas Slovenije, 1998). Prav zaradi pomembnosti izseljenstva za slovenski narod je potrebno tem tematikam v okviru raziskovanja migracij nameniti posebno mesto. Primerna obravnava omenjenih vsebin bi lahko pomembno prispevala k pozitivnemu odnosu vseh nas do lastnega naroda, spoštovanju različnosti med posameznimi skupinami slovenskih izseljencev in diaspore in, nenazadnje, tudi k ohranitvi slovenske kulturne dediščine med slovenskimi izseljenci in diasporo po svetu. Obenem bi lahko pomembno vplivala na oblikovanje pozitivnega medkulturnega dialoga in narodne identitete.

$\mathrm{Z}$ migracijami povezane vsebine bi morale postati pomembna tema tudi v slovenskih vzgojno-izobraževalnih ustanovah, ne le zaradi sodobnih migracijskih tokov 21. st., pač pa tudi zaradi vpetosti slovenskega naroda $\mathrm{v}$ migracijske procese.

\section{METODOLOGIJA}

V prvem delu prispevka smo za pojasnitev teoretičnih in terminoloških izhodišč izseljenstva uporabili primerjalno-interpretativno metodo, saj smo s pomočjo raziskovanja migracij in izseljenstva izluščili nekaj ključnih teorij preučevanja migracij in terminov, ki so neposredno povezani s procesom izseljevanja. V drugem delu prispevka smo prikazali rezultate dela empirične raziskave, ki je potekala v šolskem letu 2013/2014 med slovenskimi učenci in dijaki treh osnovnih šol, treh gimnazij ter treh srednjih strokovnih in poklicnih šol. V raziskavi je sodelovalo 687 učencev in dijakov, od tega je bilo $36,2 \%$ osnovnošolcev, 27,8 \% dijakov gimnazij in 36,0 \% dijakov srednjih strokovnih in poklicnih šol. V okviru raziskave smo od učencev in dijakov s pomočjo pisnega anketnega vprašalnika želeli pridobiti informacije o njihovem poznavanju slovenskega izseljenstva in diaspore ter njihovem zanimanju za omenjeno tematiko. $\mathrm{V}$ ta namen smo v poizvedovalni del anketnega vprašalnika vključili vprašanja, ki se nanašajo na njihovo znanje, torej poznavanje in razumevanje tematike izseljenstva na eni strani, ter vprašanja, vezana na njihov odnos do te tematike.

Ker smo učence in dijake povpraševali po znanju, smo se odločili za pisno različico anketnega vprašalnika, ki so ga učenci in dijaki izpolnili pri pouku, saj smo le na tak način lahko zagotovili veljavnost odgovorov. Če bi se poslužili spletne različice anketiranja in 
bi anketiranci lahko anketo izpolnjevali doma, bi lahko prišlo do napak pri ugotavljanju dejanskega znanja učencev in dijakov, saj bi nekateri pri pisanju odgovorov morda uporabili spletne ali druge vire.

Za potrebe prispevka smo iz poizvedovalnega dela anketnega vprašalnika izbrali vprašanja, ki se nanašajo na poznavanje in razumevanje terminologije izseljenstva. Ker smo želeli ugotoviti tudi, ali anketiranci poznajo razlike med termini izseljenec, zdomec in zamejec, smo v empiričnem delu pregledali zapisane definicije vseh treh pojmov. Pri ugotavljanju razumevanja teh treh pojmov smo uporabili metodo odprtih odgovorov, kar pomeni, da so morali učenci in dijaki po svoje dokončati začete povedi »Izseljenec je oseba, ki ...«, »Zamejec je oseba, ki ...« in »Zdomec je oseba, ki ...«.

Za metodo odprtih odgovorov smo se odločili, ker smo želeli ugotoviti, ali anketirani učenci in dijaki poznajo in razumejo razlike v definicijah, saj se vsi trije našteti pojmi obravnavajo tako v osnovnošolskem kot srednješolskem izobraževanju in so prisotni tudi v učnih načrtih in učbenikih za geografijo. Gre torej za pojme, o katerih se učenci in dijaki pri pouku geografije učijo.

V nadaljevanju smo ugotavljali tudi, ali anketiranci poznajo pojme diaspora, asimilacija, multikulturalizem in remigracija. Ker teh pojmov ni v učnih načrtih in učbenikih za geografijo, smo se odločili za metodo zaprtih, torej že vnaprej ponujenih odgovorov, izmed katerih so morali učenci in dijaki izbrati najbolj pravilnega. Pravilnost napisanih/ izbranih definicij smo analizirali s programom SPSS. Rezultati opravljene analize nam dajo vpogled v poznavanje terminologije izseljenstva med učenci in dijaki in so lahko dobra podlaga za prihodnje vsebinsko načrtovanje učnih načrtov.

\section{TEORETIČNA INTERMINOLOŠKA IZHODIŠČA MIGRA- CIJ IN IZSELJENSTVA}

\section{I.Zgodovinski in teoretični pregled preučevanja migracij}

Ljudje smo se od nekdaj selili, vendar so migracije kot znanstveno področje raziskovanja $\mathrm{v}$ znanost vstopile precej pozno. Nekateri postavljajo osnove migracijskih študij v drugo polovico 19. st. (K. Marx, F. Engels in F. Weber), drugi navajajo, da je migracije kot znanstveno kategorijo uveljavil E. G. Ravenstein (1876), tretji pa kot začetnika migracijskih študij navajajo W. Thomasa in F. Znanieckega (1918-1920). Vse do preloma 20. st. so bile migracije bolj ali manj na obrobju znanstvenih raziskovanj, po tem obdobju pa so postopoma dobivale vse pomembnejše mesto (Lukšič-Hacin, 1999). Danes se z migracijami ukvarjajo številne znanstvene discipline in so tako postale izrazito interdisciplinarno in multidisciplinarno področje raziskovanja.

V sodobnih znanstvenih razpravah se pri preučevanju migracij najpogosteje uporabljajo trije glavni teoretični pristopi, in sicer: teorija o dejavnikih odbijanja in privlačevanja ('push-pull' dejavniki) oziroma t. i. neoklasični ekonomski pristop, zgodovinsko-strukturni pristop in teorija migracijskih sistemov (Castles, Miller, 1998).

Teorija o dejavnikih odbijanja in privlačevanja skuša razložiti vzroke, selektivnost, smer in obseg migracijskih gibanj preko delovanja dejavnikov privlačevanja ('pull 
factors') in odbijanja ('push factors') (Lukšič-Hacin, 1999). Poudarja težnje ljudi, da se preselijo iz gosto na redko poseljena območja, iz območij z nižjim na območja z višjim ekonomskim standardom, ali pa se preselijo v okviru t. i. poslovnega kroga. Dejavniki odbijanja v teh primerih posameznike 'prisilijo', da zapustijo območje (kraj, državo itd.), kjer so živeli prej, medtem ko dejavniki privlačevanja 'privabijo' ljudi, da se naselijo na določenih območjih (kraj, država itd.). Castles in Miller (1998) uvrščata med dejavnike odbijanja demografsko rast, nizek dohodek, ekonomsko stagnacijo, politično preganjanje, medtem ko Klinar (1976) k naštetim dodaja še zmanjševanje naravnih virov, brezposelnost, poleg politične še druge vrste diskriminacije, majhne možnosti vplivanja ali participacije, alienacijo, naravne nesreče in omejene možnosti za osebni razvoj. Med dejavnike privlačevanja omenjena avtorja prištevata možnosti za zaposlitev, razpoložljivost prostora, ekonomsko rast in politično svobodo (Castles, Miller, 1998). Klinar (1976) $\mathrm{k}$ tem dodaja še izobraževalne možnosti, povezano družinsko in sorodstveno življenje, možnosti za koristno izkoriščanje prostega časa (kulturne in rekreacijske možnosti) ter možnosti za strokovno povezovanje.

Pri ocenjevanju dejavnikov obstajajo precejšnje razlike med emigrantsko in imigrantsko družbo. Medtem ko so negativni in pozitivni dejavniki emigrantske družbe izseljencem poznani, so jim dejavniki imigrantske družbe bolj ali manj neznani (Klinar, 1976). O njej imajo pogosto le sliko, ki si jo ustvarijo zgolj na osnovi posredovanih, mnogokrat pomanjkljivih informacijah, ne pa na osnovi neposrednih izkušenj (Lukšič-Hacin, 1999). Pri ocenjevanju te teorije je potrebno upoštevati nekaj kritičnih pomislekov. Pričakovati bi morali, da bi se najštevilčneje izseljevali najrevnejši prebivalci iz revnih v bogata območja. Empirične študije so pokazale, da so migracijski tokovi najrevnejših iz revnih v bogata območja zelo šibki (Castles, Miller, 1998). Vzrok za takšno stanje gre po Klinarju (1976, str. 25) iskati v dejstvu, da migrante »... označujemo za aktivne in inovatorske dele prebivalstva, in spričo tega emigrirajo predvsem tisti, ki se dobro zavedajo svojega nizkega statusa, prikrajšanj in alienacije v svoji emigrantski družbi in hkrati svojih možnosti v imigrantski družbi. Ker pa je pri velikem delu prebivalstva iz nerazvitih območij takšna zavest relativno slabo prisotna, je tudi obseg emigracij iz teh območij relativno majhen.« .Teorija 'push-pull' modela nadalje predpostavlja izseljevanje iz gosto poseljenih na redkeje poseljena območja. To lahko npr. izpodbijamo s primerom Nemčije in Nizozemske, ki sta državi priseljevanja in obenem tudi eni najgosteje poseljenih držav v Evropi (gostota poselitve je leta 2013 v Nemčiji znašala 231 prebivalcev $/ \mathrm{km}^{2}$, na Nizozemskem 498 prebivalcev $/ \mathrm{km}^{2}$ ) (Population density, 2014). S to teorijo tudi ne moremo pojasniti vzrokov, zakaj nekateri migranti za svojo državo priselitve raje izberejo eno, drugi pa drugo državo: npr., zakaj se večina Alžircev priseli v Francijo, medtem ko se večina Turkov v Nemčijo? S temi predpostavkami se strinja tudi Stark (1991; cv: Castles, Miller, 1998), ki pravi, da migracijskih tokov ne moremo razlagati zgolj na podlagi dohodkovnih razlik med dvema državama, ampak moramo upoštevati še številne druge dejavnike. Klinar (1976, str. 25) tako pri evalvaciji teorije odbijanja in privlačevanja zaključi, da »... le s teorijo o dejavnikih odbijanja in privlačevanja ni mogoče preprosto obrazložiti vzrokov in motivov migracij, ker gre za zapleten in kompleksen socialni fenomen. Pri analizi vzrokov migracij je treba podrobno analizirati socialno okolje in ugotoviti posamezne 
vrste objektivnih dejavnikov odbijanja in privlačevanja, zgodovinske karakteristike obeh družb in še posebej vpliv tradicije v emigrantski družbi.« Posebej poudarja, da je potrebno upoštevati tudi vrsto subjektivnih dejavnikov, racionalnih in emocionalnih elementov ter osebnostne socialno-psihološke lastnosti posameznika (Klinar, 1976).

Kot alternativa prej omenjeni teoriji odbijanja in privlačevanja se je od 70. let 20. st. dalje začel uveljavljati t. i. zgodovinsko-strukturni pristop k preučevanju migracij. Zagovorniki tega pristopa kritizirajo 'push-pull model', saj naj bi bila predpostavka, da je vzrok za migracije predvsem svobodna izbira posameznika, bolj ali manj nerealna. Poudarjajo, da so obsežni migracijski tokovi povezani predvsem z možnostmi množičnega zaposlovanja in s tem povezanega razpoložljivega kapitala (npr. selitve večjega števila ljudi, tudi Slovencev, v Nemčijo zaradi zaposlovanja v industriji v 60. in 70. letih 20. st.) (Castles, Miller, 1998).

Obe omenjeni teoriji imata pri pogledu na migracije torej izrazito enostranski pristop: prva popolnoma zanemarja zgodovinske vzroke migracij in vlogo države, medtem ko vidi druga kot dominantni vzrok migracij zlasti kapital ter poudarja množičnost migracij, medtem ko postavlja ob stran individualne odločitve za selitve (Castles, Miller, 1998).

Kot rezultat omenjenih kritik se je v okviru preučevanja migracij pojavil nov pristop, t. i. teorija migracijskih sistemov, ki v kontekstu migracij poudarja mednarodne odnose, politične sisteme, kolektivne ukrepe in institucionalne dejavnike. Migracijski sistem tako sestoji iz dveh ali več držav, ki si na podlagi različnih dejavnikov (vzrokov) 'izmenjujejo' migrante. Posebej poudarjajo, da je pri migracijah potrebno preučiti oba konca selitvenega toka (območje odselitve in območje priselitve) in obenem preučiti tudi njune medsebojne povezave, oziroma vzroke selitev iz enega na drugo območje. Prav tako poudarjajo, da moramo na migracijske tokove gledati kot na rezultat makro- in mikrostruktur, pri čemer se makrostrukture nanašajo na obsežne institucionalne dejavnike (politične sisteme svetovnega trga, odnose med državami, migracijske zakone držav), mikrostrukture pa so vezane na posameznike in njihove odločitve (Castles, Miller, 1998).

Pregled teoretičnih izhodišč preučevanja migracij kaže torej na različne pristope raziskovanja in dojemanja migracijskih tokov. Tudi danes znanstvene discipline nimajo poenotenih stališč do migracij, poudariti pa je treba, da migracij ne moremo in ne smemo dojemati kot enoznačen termin, temveč kot »... zapleten in kompleksen socialni fenomen« (Klinar, 1976, str. 25).

\subsection{Terminološka izhodišča izseljenstva}

$\mathrm{Z}$ migracijami in izseljenstvom je povezanih kar nekaj pojmov, po katerih poznavanju in razumevanju smo v raziskavi spraševali učence in dijake. Pred kvantitativno analizo rezultatov raziskave želimo pojme, ki se posredno ali neposredno vežejo na tematiko izseljenstva (izseljenec, zdomec, zamejec, diaspora, asimilacija, multikulturalizem in remigracija) tudi predstaviti v teoretičnem kontekstu. Da bi dobili jasnejši vpogled v razumevanje terminologije s strani učencev in dijakov, smo poleg znanstvene in strokovne literature pri oblikovanju definicij pregledali tudi obstoječe geografske učbenike in analizirali definicije oziroma razlage zgoraj navedenih terminov v njih. 
V Slovarju slovenskega knjižnega jezika je izseljenec opredeljen kot »kdor se izseli v tujino«. Nekoliko natančnejšo definicijo podaja Mednarodna organizacija za migracije (IOM), ki navaja, da je izseljenec oseba, ki se preseli v tujo državo in živi tam najmanj 12 mesecev (International migration law, 2004). Isti vir navaja, da je izseljenec tudi oseba, ki zapusti svojo rojstno državo z namenom, da bi živel v drugi državi. Omeniti moramo, da se v tuji literaturi namesto pojmov izseljenec ali priseljenec pogosteje uporablja nekoliko bolj nevtralen pojem migrant (slovensko selivec), saj pri slednjih dveh pojmih posebej poudarjamo smer gibanja oziroma selitve - odselitve ali priselitve. Tako je ista oseba za državo izselitve izseljenec, za državo priselitve pa priseljenec.

$\mathrm{Na}$ spletni strani Urada za Slovence v zamejstvu in po svetu je zapisano, da so Slovenci po svetu »... po besedilu Zakona o odnosih Republike s Slovenci zunaj njenih meja zdomci in izseljenci, ki bivajo v sosednjih državah zunaj območja opredeljenega kot zamejstvo in v ostalih evropskih ter izven-evropskih državah. Tako imamo pravzaprav dve kategoriji Slovencev po svetu: zdomci in izseljenci.« (Slovenci po svetu, 2014). Isti vir tudi navaja, da so določeni »... razlogi narekovali tudi nastanek slovenskega izseljenstva, ki pa se nahaja v državah preko oceanov. Tako so velike slovenske skupnosti v ZDA, Kanadi, Argentini in ostalih državah Latinske Amerike, Avstraliji ter državah Azije, Afrike in Oceanije, vendar v slednjih v manjšem številu. «(Slovenci po svetu, 2014).

Po tem zapisu imamo torej Slovenci svoje izseljenske skupnosti le izven Evrope, medtem ko so slovenski zdomci samo v drugih evropskih državah in jih na ostalih kontinentih ni. Po našem mnenju ta definicija ni najustreznejša, saj so tudi v Evropi slovenske izseljenske skupnosti, o katerih so pisali že številni raziskovalci, prav tako pa tudi pojav zdomstva ni več vezan le na evropski kontinent, kot je to večinoma bil v drugi polovici 20. st. Zaradi sodobnih migracijskih tokov, vzrokov in nenazadnje tudi mobilnosti ne moremo več vezati slovenskega zdomstva samo na nekatere evropske države, saj se pojavlja tudi v ostalih delih sveta.

Ena izmed pomembnih ločnic v razlikovanju pojmov izseljenec in zdomec bi bila prav gotovo na eni strani časovna komponenta, na drugi pa definiranje vzroka stalne oziroma začasne izselitve. Izseljenec bi potemtakem bil oseba, ki se za vedno izseli iz neke države in priseli v drugo zaradi različnih vzrokov, medtem ko bi pri pojmu zdomec govorili o osebi, ki se začasno preseli v drugo državo zaradi dela. Seveda se nam tudi pri omenjenih definicijah odpirajo nekatera vprašanja. Prvo je vprašanje začasnosti: kaj v definiciji zdomstva začasnost sploh pomeni? Govorimo o začasni preselitvi takrat, ko se nekdo preseli v drugo državo za nekaj mesecev ali za nekaj let? Ali je pri opredelitvi zdomstva in izseljenstva pomemben dejavnik stalnega prebivališča? O tem ne govori nobena definicija, vsekakor pa je pomislek o lokaciji stalnega prebivališča tudi pomemben. Že na podlagi teh nekaj naštetih vprašanj vidimo, da je definiranje izseljenstva in zdomstva, ki se na prvi pogled zdi enostavno, pravzaprav kompleksno.

$\mathrm{Z}$ vidika naše raziskave je še posebno zanimiva opredelitev obravnavanih pojmov v šolskih učbenikih za geografijo. Učbenik Geografija Slovenije (za 9. razred osnovne šole) navaja, da »... če se ljudje odselijo v drugo državo ... za trajno, govorimo o izseljencih« (Senegačnik, 2012, str. 39). Podobno navaja učbenik Raziskujem Slovenijo 9, da so izseljenci »... ljudje, ki so se za stalno odselili v tujino« (Verdev, 2011, str. 35). Navadno sta 
pojma izseljenci in zdomci omenjena $\mathrm{v}$ učbenikih skupaj, le da se pri izseljencih poudarja stalnost izselitve, pri zdomcih pa njihovo začasnost. Tudi učbenik Živim v Sloveniji (9. razred osnovne šole) navaja, da moramo pri »... odseljevanju v tujino ločiti izseljence in zdomce. Izseljenci se odselijo za stalno, zdomci pa le začasno (za nekaj let), potem pa se vrnejo domov.« (Senegačnik, Drobnjak, Otič, 2007, str. 43).

V učbeniku Obča geografija (1. letnik gimnazije) so izseljenci definirani z naslednjim opisom: »Ko ljudje zapustijo prvotni kraj bivanja, so emigranti, ko pa se priselijo v novi kraj bivanja, so imigranti.« (Senegačnik, Drobnjak, 2010, str. 147). Za razliko od osnovnošolskih definicij je pri srednješolski (gimnazijski) tokrat poudarjena le sprememba kraja in ne več države. Učbenik Geografija 1 (1. letnik gimnazije) pa definicije izseljenca ne podaja, pojasni le tuji besedi: »... izseljencem s tujko pravimo emigranti, priseljencem pa imigranti.« (Popit, 2011, str. 142).

Termin zdomec smo nekajkrat omenili že v prejšnjem odstavku, saj se v slovenskih geografskih učbenikih pogosto uporablja v povezavi s pojmom izseljenec. Za razliko od tuje literature smo v Sloveniji v drugi polovici 20. st. 'skovali' izraz zdomec, ki ga lahko enačimo $\mathrm{z}$ angloameriškim izrazom 'migrant worker', oziroma delavec na začasnem delu v tujini. Po definiciji IOM je torej zdomec oseba, ki začasno zapusti svojo domovino oziroma rojstno državo zaradi želje po boljšem življenju oziroma izboljšanju kvalitete življenja, ko se v tuji državi začasno zaposli (International migration law, 2004). Po definiciji Združenih narodov pa je zdomec vsaka oseba, ki dela izven svoje domovine (International convention ..., 1990). Urad za Slovence v zamejstvu in po svetu omenja, da so pri zdomcih »... razlogi za odhod iz matične domovine predvsem ekonomske narave.« (Slovenci po svetu, 2014). V Geografskem atlasu Slovenije (1998, str. 170) so slovenski zdomci opredeljeni kot »... ljudje, ki imajo stalno bivališče v Sloveniji, vendar zaradi dela ali študija začasno bivajo v drugih državah; čez nekaj časa se imajo namen vrniti v domovino. Med zdomce prištevamo še družinske člane, ki so s temi ljudmi začasno v tujini. Zanje se uporablja tudi opisni izraz delavci na začasnem delu v tujini in njihovi družinski člani.«.

V nekaterih osnovnošolskih geografskih učbenikih termin zdomec ni posebej opredeljen kot rezultat ekonomske migracije, saj je npr. definiran z opisom »Če se ljudje odselijo v drugo državo le začasno (za nekaj let), govorimo o zdomcih ...« (Senegačnik, 2012, str. 39). V nadaljevanju v istem učbeniku piše, da so vzroki za odseljevanje »... večinoma politični, gospodarski, družinski in zdravstveni« (Senegačnik, 2012, str. 39). Senegačnik torej pri terminu zdomec sploh ne poudarja ekonomskega vzroka začasne izselitve, temveč postavlja v ospredje zgolj začasnost. Po njegovem opisu lahko sklepamo, da naj bi bili torej vzroki izselitve (stalne ali začasne) izseljencev in zdomcev popolnoma enaki.

Učbenik Raziskujem Slovenijo 9 (Verdev, 2011, str. 35) izpostavlja, da so »... zdomci ljudje, ki imajo stalno bivališče v Sloveniji, vendar začasno bivajo v drugih državah.«. V prvem stavku definicije tudi Verdevova ne izpostavlja ekonomskega vzroka začasne izselitve. Kljub temu v nadaljevanju opisovanja pojma zapiše, da naj bi v tujini »... delalo ali študiralo okoli 50.000 Slovencev ... Iz Slovenije so ljudje na začasno delo v tujino v večjem številu začeli odhajati po letu 1965, sredi 70-tih let se je njihovo število začelo postopno zmanjševati. ... V zadnjem času se povečuje število mladih, ki odhajajo na študij v tujino.« V nadaljevanju opisovanja pojma Verdevova torej izpostavi ekonomski 
vzrok kot poglavitnega za odhod zdomcev, $\mathrm{k}$ temu pa dodaja še potrebo/željo po šolanju $\mathrm{v}$ tujini, kar preostali geografski učbeniki ne omenjajo.

Učbenik Obča geografija (Senegačnik, Drobnjak, 2010, str. 146) piše, da sodijo med začasne selitve $» . .$. selitve delavcev na začasno delo $v$ tujino. Takšnim migrantom pravimo zdomci. V tujini delajo več let, potem pa se vrnejo domov.«

Iz navedenih definicij vidimo, da se med seboj precej razlikujejo, zlasti glede vzroka migracij zdomcev. Iz tega lahko razberemo kompleksnost definiranja osnovnih pojmov, obenem pa se izpostavlja vprašanje, ali bi bilo potrebno v šolskih učbenikih za boljše razumevanje pojem zdomstvo opisati bolj jasno in ga uskladiti z mednarodno terminologijo. Po našem mnenju je to potrebno, saj smo ugotovili, da več kot polovica v raziskavi sodelujočih učencev in dijakov termina zdomec sploh ne pozna. Morda lahko iščemo vzrok takšnih rezultatov tudi v nejasni/nedosledni opredelitvi pojma $v$ geografskih učbenikih.

Pojem zamejci seveda ni povezan s procesom migracij ljudi, temveč v nekem smislu $\mathrm{z}$ 'migracijo meje'. Ker pa se pojmi izseljenstvo, zdomstvo in zamejstvo $\mathrm{v}$ šolskih geografskih učbenikih pogosto pojavljajo skupaj in ker učenci in dijaki omenjene pojme med seboj tudi 'pomešajo', smo v tem prispevku želeli pojasniti tudi pojem zamejci. Po zapisu Urada za Slovence v zamejstvu in po svetu so »Slovenci v zamejstvu ali zamejski Slovenci naši rojaki, ki prebivajo v zamejstvu; slovensko zamejstvo pa so tista obmejna področja štirih sosednjih držav, kjer živi avtohtona slovenska narodna skupnost. V obmejnih področjih sosednjih držav so Slovenci torej avtohtono prebivalstvo, saj njihova naseljenost na tistem ozemlju sega v davnino.« (Slovenci v zamejstvu, 2014).

V učbeniku Geografija Slovenije (Senegačnik, 2012, str. 46) so Slovenci v zamejstvu opisani kot Slovenci, »ki živijo kot avtohtona narodna manjšina na bližnjih obmejnih območjih v Italiji, Avstriji in na Madžarskem.«. Učbenik Raziskujem Slovenijo 9 (Verdev, 2011, str. 34) najprej izpostavi splošno definicijo zamejstva in potem primer iz Slovenije: zaradi »... sprememb državnih meja, ki niso vedno sledile mejam med narodi, se danes v številnih državah državna meja (loči dve državi) in narodna meja (loči dva naroda) ne ujemata. Podobno je tudi v Sloveniji. Slovenci v zamejstvu so del slovenskega naroda, ki zaradi spremembe meje $\mathrm{v}$ preteklosti danes živijo na narodno mešanem ozemlju v Italiji, Avstriji ter na Madžarskem.«. Učbenik Obča geografija (Senegačnik, Drobnjak, 2010, str. 155) pojma zamejci ne omenja, definira pa pojem narodne manjšine kot »... del naroda, ki je zaradi zgodovinskega razvoja zunaj meja države matičnega naroda.«

Naslednji štirje pojmi (diaspora, asimilacija, multikulturalizem in remigracija), ki jih bomo $\mathrm{v}$ teoretičnem orisu na kratko predstavili, niso opisani $\mathrm{v}$ nobenem od navedenih geografskih učbenikov. Na podlagi rezultatov raziskave lahko ugotovimo, da učenci in dijaki nekatere od teh pojmov kljub temu poznajo, predvsem zaradi njihove splošne uporabe v vsakdanjem življenju.

V dokumentu Mednarodne organizacije za migracije se pojem diaspora nanaša na ljudi ali etnično skupino, ki (je) zapusti(la) svojo tradicionalno domovino in se razseli(la) po drugih delih sveta (International migration law, 2004). Gre torej za skupino ljudi, ki imajo skupen izvor (etnično pripadnost) in se naselijo na nekem drugem prostoru.

Eno izmed definicij asimilacije sta postavila Park in Burgess leta 1921, ko sta asimilacijo opredelila kot rezultat $\gg . .$. procesa interpretacije in fuzije, $v$ katerem si osebe in 
skupine pridobijo spomin, emocije in držo drugih ljudi ali skupin.« (Lukšič-Hacin, 1999). Bolj preprosto povedano naj bi bila asimilacija proces kulturnega prilagajanja posameznika ali manjšine večinskemu, prevladujočemu delu prebivalstva.

Po mnenju Lukšič-Hacinove (1999) lahko multikulturalizem pojasnimo na tri načine, in sicer s tem pojmom samo »... opisujemo realnost, ko se v isti državi nahaja več različnih kulturnih ali/in etničnih skupin; lahko se uporablja kot teoretska kategorija za analiziranje odnosov med različnimi kulturami in/ali etničnimi skupnostmi, ali pa se multikulturalizem pojavlja v političnih programih in gibanjih, ki zagovarjajo spremembe obstoječih odnosov med dominantno kulturo in t. i. avtohtonimi etničnimi manjšinami, ali na drugi strani kot princip uradne državne politike do priseljencev.« (Milharčič-Hladnik, 2009, str. 145-146).

$\mathrm{V}$ tuji literaturi je pojem remigracija (angl. return migration) opisan kot selitev osebe oziroma posameznika, ki se preseli v svojo prvotno domovino po tem, ko je najmanj eno leto živel v drugi državi. Ta vrnitev je lahko prostovoljna ali prisilna (International migration law, 2004). Slovenski izraz za remigracijo je povratnišvo, ki pa ni niti prostorsko niti časovno enotno opredeljeno. Nekateri avtorji povezujejo koncept remigracije izključno z mednarodnimi migracijami, drugi ta pojem povezujejo tudi z notranjimi migracijami. Enoznačnega odgovora na vprašanje, koliko časa mora posameznik preživeti drugje, da ga lahko po vrnitvi domov označimo za povratnega migranta ni. IOM sicer meni, da mora človek živeti v tujini najmanj 12 mesecev in se šele po preteku tega časovnega obdobja ter preselitvi nazaj v prvotno domovino lahko šteje za remigranta, torej povratnika (Komac, Medvešek, 2005, str. 219).

\section{POZNAVANJETERMINOLOGIJE IZSELJENSTVA MED UČENCI IN DIJAKI}

Ker menimo, da bi morale biti migracije in z njimi povezano izseljenstvo ustrezno zastopane tudi v slovenskem vzgojno-izobraževalnem procesu, ne le zaradi aktualnih (globalnih) migracijskih trendov in procesov, marveč tudi zaradi vpetosti slovenskega naroda in prostora $\mathrm{v}$ migracijske procese, smo po poznavanju nekaterih migracijskih terminov $\mathrm{v}$ raziskavi spraševali slovenske učence in dijake. Zanimalo nas je, ali znajo učenci in dijaki pravilno pojasniti pojme izseljenec, zdomec in zamejec in ali poznajo pojme diaspora, asimilacija, multikulturalizem in remigracija ter med naštetimi ponujenimi definicijami izbrati pravilno. Zanimalo nas je tudi, ali se poznavanje terminologije s starostjo spreminja. Glede na učno snov predmeta geografija lahko pričakujemo, da bodo učenci 6 . razreda osnovne šole poznali manj naštetih terminov kot učenci 9. razreda, oziroma naj bi dijaki tretjih in četrtih letnikov termine poznali veliko bolje kot osnovnošolci.

Glede pojma izseljenec je raziskava pokazala, da 62,9 \% vseh sodelujočih učencev in dijakov pojem izseljenec pozna zelo dobro in so v prostih odgovorih na anketne vprašalnike zapisali popolno definicijo. Za popolno definicijo smo šteli vse odgovore, v katerih sta bili poudarjeni tako časovna kot prostorska komponenta in so tako dijaki kot učenci v definicijah omenili »stalnost preselitve « in »preselitev v tujo državo«. Tako so nekateri osnovnošolci zapisali, da je izseljenec oseba, ki »se za vedno izseli v drugo državo«, »se za stalno preseli v drugo državo«, »se je za vedno izselil iz svoje države v drugo«, »se 
izseli iz neke države v drugo«. Gimnazijci so npr. zapisali, da je izseljenec oseba, ki »se za stalno izseli iz države«, »se za stalno izseli iz države zaradi različnih razlogov«, »se je za zmeraj izselil iz domače države«, dijaki srednjih strokovnih in poklicnih šol pa, da je izseljenec oseba, ki »se je za stalno izselila iz rojstne države«, »se za vedno izseli v drugo državo«, »se je za stalno izselila iz svoje domovine in priselila v drugo državo«.

29 \% vseh sodelujočih učencev in dijakov je podalo delno pravilno definicijo izseljenca, kar pomeni, da iz zapisane definicije ni moč razbrati njihovega popolnega razumevanja termina izseljenec. Tako smo med delno pravilne razlage šteli npr. zapise učencev osnovnih šol, da je izseljenec oseba, ki »se je izselila« (v tem zapisu ni jasno podana prostorska komponenta, torej od kod se je oseba izselila - iz kraja, doma, države?), »se je izselila iz Slovenije v drugo državo« (tak odgovor je le delno pravilen, saj so izseljenci vsi, ki so se izselili iz katere koli države, torej ne le iz Slovenije), »se izseli in se nima namena vrniti« (zopet manjka prostorska komponenta, ki mora biti po našem mnenju točneje definirana), »je izgnana iz neke države« (delno pravilno, ker ni nujno, da so vsi izseljenci t. i. politični emigranti in izgnanci; mnogi se sami odločijo in izselijo iz države), »je izseljena iz države« (takšna definicija predpostavlja, da je izseljenec oseba, ki se sama ne odloči za izselitev iz države, temveč ga v to prisilijo drugi).

Izmed vseh anketiranih je 4,8 \% učencev in dijakov zapisalo nepravilno definicijo termina izseljenec, polovica izmed njih je osnovnošolcev. Nekateri so npr. zapisali, da je izseljenec oseba, ki »živi v državah, ki niso sosednje«, »se seli«, »se izseljuje v druge kraje«, »se izseljuje«, »se izseli iz stanovanja«. Dijaki srednjih strokovnih in poklicnih šol so napačno zapisali, da izseljenec »ni več državljan Slovenije«, »se je izselil iz države za nekaj časa «, »živi v drugi državi«, »ne živi več na svojem ozemlju«, »se iz enega kraja preseli v drug kraj«, gimnazijci pa, da »živi v neki drugi državi«, »se je izselil iz stalnega prebivališča«, »se je začasno izselil iz domačega kraja«. Pri nepravilnih definicijah je torej moč razbrati, da nekateri učenci ali dijaki pojma izseljenec ne poznajo in ga zato tudi napačno definirajo, nekateri pa pojem izseljenec zamenjujejo celo s pojmom zdomec. Raziskava je tudi pokazala, da pojem izseljenec pravilneje in natančneje definirajo dijaki srednjih šol (gimnazij in srednjih strokovnih šol) kot učenci osnovnih šol.

Glede pojma zdomec je raziskava pokazala nekoliko drugačne rezultate kot pri opredelitvi prvega termina. Največji odstotek učencev in dijakov (33,2 \% sodelujočih) termina zdomec ni definiralo pravilno. Če k temu odstotku prištejemo še tiste, ki definicije sploh niso zapisali (20,7 \%), dobimo podatek, da 53,9 \% sodelujočih pojma zdomec ne pozna, oziroma ga ne zna definirati. Za pravilne zapise smo šteli tiste definicije, ki so vsebovale tako prostorsko komponento izselitve v tujino kot časovno komponento začasnosti preselitve. Izmed vseh sodelujočih je 28,4 \% učencev in dijakov podalo popolno definicijo pojma zdomec. Osnovnošolci so npr. zapisali, da je zdomec oseba, ki »dela v drugi državi in ne v tisti, iz katere je doma«, »je odšel zaradi službe začasno v drugo državo« in »začasno živi v tujini zaradi dela«. Zgolj štirje učenci treh osnovnih šol $(1,6 \%)$ so podali popolno definicijo tega pojma.

Kot primere popolno zapisanih definicij pojma zdomec, ki so jih zapisali gimnazijski dijaki, lahko navedemo sledeče: zdomec je oseba, ki »zaradi službe le začasno živi v drugi državi«, »živi izven svoje države začasno«, »se preseli začasno v tujino«, »je začasno v 
tujini in se bo vrnila«, »se zaradi dela preseli v tujino in se namerava vrniti«. Dijaki srednjih strokovnih in poklicnih šol so kot primere popolnih definicij zapisali, da je zdomec oseba, ki »se začasno izseli iz države«, »začasno živi izven svoje države«, »začasno dela v tujini«, »se izseli zaradi službe in se namerava vrniti nazaj«.

Pomembna komponenta popolnosti definicije je bil torej pogoj začasnosti preselitve. Osnovnošolci so npr. nepravilno zapisali, da je zdomec oseba, ki »ne živi doma«, »se izseli iz svoje domovine največkrat pod prisilo«, »ima dom, ampak živi tam občasno«, »so ga izgnali iz doma«, »je velikokrat z doma«, »živi v rojstni državi«, »je z doma«, »zbeži od doma«. Nekateri gimnazijski dijaki so zapisali, da je zdomec oseba, ki »je bil zaradi nevšečnosti prisiljen v izselitev«, »ga čez dan ni doma zaradi službe/šole«, »gre začasno iz doma«, »je prisiljena zapustiti matično državo«, dijaki srednjih in strokovnih šol pa, da je zdomec oseba, ki »živi proč od doma«, »ni v svojem domu, je kje drugje«, »je iz države izseljen za stalno«, »je za nekaj časa šel od doma«, »je začasno proč od doma«.

Pri definiranju termina zamejec je največ učencev in dijakov $(53,9 \%)$ podalo delno pravilno definicijo, 30,6 \% popolno in 6,0\% nepravilno definicijo, 9,5\% sodelujočih pa definicije ni zapisalo. Kot primere popolnih definicij so učenci osnovnih šol zapisali, da je zamejec oseba, ki »živi v sosednji državi v narodni manjšini«, »živi za mejo svoje države zaradi spreminjanja mej med vojnami«, »za mejo matične države«, »na drugi strani meje njegove rojstne države, v manjšini«, »živi za mejo svoje države, čeprav ima njihovo narodnost«. Dijaki gimnazij so mdr. napisali, da je zamejec oseba, ki »živi na ozemlju za mejo svoje države, ki zaradi zgodovinskih premikov državnih mej ne pripada več tej državi«, »živi ob meji s svojo matično državo«, »živi tik ob meji (izven države) in je nekoč pripadal tej državi«, »je pripadnik narodne manjšine izven matične države v bližini njene meje«. Dijaki srednjih strokovnih in poklicnih šol so navedli, da je zamejec oseba, ki »je zaradi spreminjanja mej v zgodovini ostala izven svoje rodne države«, »živi čez mejo svoje države«, »živi v sosednji državi, ker se je zaradi političnih vzrokov meja države spremenila in je ostal na drugi strani meje«.

Med nepravilne definicije smo šteli opise osnovnošolskih učencev, da je zamejec oseba, ki »je na meji ob Sloveniji«, »pride iz za meje«, »se je preselil na drugo stran meje«, »ki je na primer Slovenec, ki živi na Hrvaškem«, »živi za mejnimi prehodi«, gimnazijskih dijakov pa, da je zamejec oseba, ki »je priseljen v drugo državo«, »je za mejo«, »živi izven meje«, »se izseli izven mej države«.

Učence in dijake smo v raziskavi spraševali tudi, ali poznajo pojme diaspora, asimilacija, multikulturalizem in remigracija. Med ponujenimi definicijami so morali izbrati tisto, ki po njihovem mnenju najbolj točno in jasno opiše omenjeni pojem.

Iz preglednice 1 lahko vidimo, da pri prepoznavanju pojma diaspora nekoliko izstopa opis definicije a, medtem ko sta ponujeni definiciji b in c enakovredni. Glede na v prejšnjem poglavju predstavljen terminološki oris, bi bila v tem delu najpravilnejša izbira b, da je torej diaspora narodnostna ali verska skupnost, ki živi na ozemlju druge narodnosti ali vere. Pri možnosti a opis definicije ustreza pojmu zamejec, pri možnosti c pa pojmu zdomec. Pri poznavanju termina diaspora lahko torej zaključimo, da je sicer 'zgolj' $14,2 \%$ anketiranih zagotovilo, da termin diaspora poznajo, a odstotek teh je še bistveno nižji, saj so rezultati pokazali, da jih izmed njih termin tudi dejansko pozna le 30,6 \%. 
Pri poznavanju pojma asimilacija sta več kot dve tretjini učencev in dijakov odgovorili, da termina ne poznajo. Med tistimi, ki so odgovorili, da pojem asimilacija poznajo $(31,9 \%$ ), jih je $78,5 \%$ pravilno izbralo možnost c, $11,5 \%$ možnost a in $6,3 \%$ možnost b. Pojem asimilacija najbolj jasno in nazorno opiše možnost c, pri možnosti a gre za opis pojma globalizacija, pri možnosti b pa za opis pojma migracija (preglednica 1).

Preglednica 1: Poznavanje pojmov diaspora, asimilacija, multikulturalizem in remigracija Table 1: Knowledge of terms diaspora, assimilation, multiculturalism and remigration

\begin{tabular}{|c|c|c|c|}
\hline Pojem & $\%^{1}$ & $\%^{2}$ & Opis definicije \\
\hline \multirow[t]{5}{*}{ Diaspora } & 84,1 & - & Ne pozna \\
\hline & 1,7 & - & Ni odgovora \\
\hline & \multirow[t]{3}{*}{14,2} & 40,0 & $\begin{array}{l}\text { a) Diaspora je etnična skupnost, ki je večinoma zaradi političnih razlogov } \\
\text { ostala zunaj svoje matične države. }\end{array}$ \\
\hline & & 30,6 & $\begin{array}{l}\text { b) Diaspora je narodnostna ali verska skupnost, ki živi na ozemlju druge } \\
\text { narodnosti ali vere. }\end{array}$ \\
\hline & & 28,2 & c) Diaspora je skupnost ljudi, ki se začasno izseli v tujino. \\
\hline \multirow{5}{*}{$\begin{array}{l}\text { Asimila- } \\
\text { cija }\end{array}$} & 66,3 & - & Ne pozna \\
\hline & 1,8 & - & Ni odgovora \\
\hline & \multirow[t]{3}{*}{31,9} & 78,5 & $\begin{array}{l}\text { a) Asimilacija pomeni vključevanje posameznikov v določeno okolje s } \\
\text { prevzemanjem njegovih značilnosti, lastnosti. }\end{array}$ \\
\hline & & 11,5 & $\begin{array}{l}\text { b) Asimilacija pomeni sklop sprememb v družbi, politiki in ekonomskem } \\
\text { sistemu, ki so posledica razširjenega trgovanja in kulturnih izmenjav na } \\
\text { globalni ravni. }\end{array}$ \\
\hline & & 6,3 & $\begin{array}{l}\text { c) Asimilacija pomeni zapuščanje domačih krajev in priselitev v drug kraj ali } \\
\text { drugo državo. }\end{array}$ \\
\hline \multirow{5}{*}{$\begin{array}{l}\text { Multikul- } \\
\text { turalizem }\end{array}$} & 58,3 & - & Ne pozna \\
\hline & 1,8 & - & Ni odgovora \\
\hline & \multirow[t]{3}{*}{39,9} & 95,2 & $\begin{array}{l}\text { a) Multikulturalizem pomeni, da se v isti državi nahaja več različnih } \\
\text { kulturnih in/ali etničnih skupin. }\end{array}$ \\
\hline & & 2,6 & b) Multikulturalizem pomeni politiko rasnega, verskega in kulturnega ločevanja. \\
\hline & & 1,1 & $\begin{array}{l}\text { c) Multikulturalizem izhaja iz prepričanja, da je določena skupina, način } \\
\text { življenja ali razmišljanja superiorna ostalim. }\end{array}$ \\
\hline \multirow{5}{*}{$\begin{array}{l}\text { Remigra- } \\
\text { cija }\end{array}$} & 53,1 & - & Ne pozna \\
\hline & 45,2 & - & Ni odgovora \\
\hline & \multirow[t]{3}{*}{1,7} & 88,5 & $\begin{array}{l}\text { a) Remigracija pomeni odhod iz imigrantske države ter vrnitev v izvorno } \\
\text { državo in ponovno vključevanje v izvorno družbeno okolje. }\end{array}$ \\
\hline & & 5,2 & b) Remigracija pomeni stalno izselitev iz izvorne države. \\
\hline & & 5,2 & $\begin{array}{l}\text { c) Remigracija pomeni mednarodno zaščito, za katero lahko zaprosi tujec ali } \\
\text { oseba brez državljanstva, ki meni, da je v matični državi preganjan zaradi poli- } \\
\text { tičnega prepričanja ali svoje verske, rasne, narodnostne ali etnične pripadnosti. }\end{array}$ \\
\hline
\end{tabular}

Vir/Source: Ilc Klun, 2014

1 Deleži odgovorov vseh anketirancev.

2 Deleži anketirancev, ki so izbrali eno od ponujenih definicij. Pri nobenem pojmu skupni seštevek ni 100 \%, saj nekateri anketiranci niso izbrali nobene od ponujenih definicij (obkrožili pa so, da pojem poznajo). 
Pri poznavanju termina multikulturalizem so bili rezultati učencev in dijakov nekoliko boljši. Zaradi vse večje uporabe pojma v vsakdanjem življenju in tudi pri različnih predmetih v šolah, je poznavanje tega pojma nekoliko boljše od poznavanja pojmov diaspora in asimilacija. Izmed vseh sodelujočih jih je 58,3 \% odgovorilo, da pojma multikulturalizem ne pozna, 39,9\% pa pojem pozna; od teh jih je kar 95,2 \% pravilno obkrožilo možnost a, 2,6 \% možnost b in 1,1 \% možnost c. Rezultat je torej pokazal, da velika večina tistih, ki so menili, da pojem poznajo, dejansko pozna tudi njegovo definicijo. Pri opisu možnosti c gre za opis termina nestrpnost, pri možnosti b pa termina apartheid.

Pri pojmu remigracija je več kot polovica učencev in dijakov odgovorila, da pojma ne pozna. Izmed vseh, ki so na vprašalniku obkrožili, da pojem remigracija poznajo (zgolj 1,7 \%), jih je 88,5 \% pravilno obkrožilo možnost a, 5,2 \% možnost b in ravno tolikšen odstotek možnost c. Pri opisu možnosti b gre za definicijo emigracije, pri možnosti c pa za definicijo pojma azil.

Če povzamemo ključne ugotovitve raziskave, lahko rečemo, da učenci in dijaki dobro poznajo pojem izseljenec (poznavanja tujke emigrant $\mathrm{v}$ raziskavi nismo preverjali), razmeroma poznan jim je pojem zamejec, čeprav so bili nekateri učenci in dijaki pri pisanju odgovorov nekoliko površni, medtem ko je poznavanje termina zdomec zelo šibko. To je presenetljivo, saj so vsi trije termini prisotni v geografskih učbenikih, oziroma so teme o izseljenstvu, zdomstvu in zamejstvu vključene tudi v pouk geografije. Glede na slabo poznavanje terminologije, se postavlja vprašanje, kako se te vsebine pri pouku poučujejo, koliko časa jim učitelji in učni načrt namenjajo ter kaj ob vsem tem učenci in dijaki sploh spoznajo.

Med ostalimi preučevanimi pojmi (diaspora, asimilacija, multikulturalizem in remigracija) učenci in dijaki najbolje poznajo pojma multikulturalizem, kar niti ne preseneča, saj je postal pojem v zadnjih nekaj letih zelo prepoznaven tudi v vsakdanjem življenju, in remigracija. Ta je zaradi sestavljene besede (re + migracija) nekoliko lažje prepoznaven in lahko učenci in dijaki na osnovi predpone re- sklepajo o njegovem pomenu. Pojmov diaspora in asimilacija pa večina učencev in dijakov ne pozna. Noben izmed obravnavanih štirih terminov tudi ni prisoten v operativnih učnih ciljih učnega načrta za geografijo.

\section{SKLEP}

Zgodovinski in teoretični pregled preučevanja migracij kažeta, da obstajajo precejšnje razlike med teoretičnimi pristopi preučevanja in dojemanja migracij. Čeprav nekatere teorije poudarjajo ekonomske dejavnike, druge vlogo posameznika ali skupine, so migracije kompleksen družbeni pojav, ki zahteva celovit pristop. Pri analiziranju migracijskih tokov moramo biti pozorni na skupek vseh dejavnikov, ki so migracijski tok povzročili - zanimati nas morajo vzroki, zakaj se je/so se posameznik/skupina ljudi odločil/odločili, da določeno območje zapustijo, in kateri so dejavniki, ki so posameznike/skupine 'pripeljali' drugam.

Poleg tega, da na migracije gledamo kot na širok, kompleksen pojav, je pomembno tudi védenje o tem, kako dobro so vsebine o migracijah zastopane v slovenskem vzgojno-izobraževalnem sistemu. Te vsebine bi morale postati pomembna tema tudi v slovenskih vzgojno-izobraževalnih ustanovah, ne le zaradi sodobnih migracijskih tokov 21. st., pač pa tudi zaradi vpetosti slovenskega naroda $\mathrm{v}$ migracijske procese in zaradi pojmov, $\mathrm{s}$ 
katerimi opredeljujemo migracije. V tem segmentu se postavljajo vprašanja, ali je poznavanje terminologije izseljenstva med šolajočimi sploh potrebno ter zakaj in kdaj naj bi učenci in dijaki v procesu izobraževanja in vzgoje usvojili posamezne pojme?

Raziskava je pokazala, da skoraj $63 \%$ učencev in dijakov zelo dobro pozna pojem izseljenec, medtem ko je pri ostalih dveh terminih (zdomec in zamejec) odstotek pravilno in popolno zapisanih definicij precej nižji. Posebej moramo izpostaviti nepoznavanje pojma zdomec, saj ga ne pozna skoraj 54 \% učencev in dijakov, čeprav je pregled učbenikov za geografijo pokazal, da se pojem v vzgojno-izobraževalnem procesu obravnava, še več, njegov opis se pojavlja skupaj z opisom izseljenstva. Zakaj si potemtakem učenci in dijaki pojem izseljenec zapomnijo, pojma zdomec pa ne? Odgovorov na to vprašanje bi lahko bilo več. Verjetno so na izseljenstvo vezane vsebine v učnem procesu poudarjene bolj natančno kot zdomstvo. Drugič, procese izseljevanja lahko ravno zaradi sodobnih migracijskih tokov obravnavajo v učnem procesu pri različnih učnih temah (ne le vezanih na slovenstvo), medtem ko se zdomstvo obravnava pri pouku geografije večinoma le pri obravnavanju začasnega izseljevanja Slovencev (deveti razred osnovne šole ter prvi in tretji/četrti letnik srednjih šol).

Pri poznavanju ostalih terminov (diaspora, asimilacija, multikulturalizem in remigracija), ki sicer niso omenjeni niti v operativnih ciljih učnih načrtov za pouk geografije v osnovni in srednji šoli, niti v učbenikih za geografijo, pa je raziskava pokazala, da jih učenci in dijaki slabo poznajo. Rezultati zaradi nezastopanosti vsebin v učnem procesu niso presenetljivi, a velja izpostaviti, da je izmed vseh omenjenih pojmov med učenci in dijaki najbolj poznan pojem multikulturalizem, verjetno zaradi njegove vse širše uporabe v vsakdanjem življenju.

Po našem mnenju bi morali učenci v osnovnošolskem izobraževanju pojme izselje$n e c$, zdomec in zamejec poznati, jih razumeti ter med seboj pravilno razlikovati. Poznavanje osnovne terminologije je namreč nujno potrebno za uresničevanje učnih ciljev višjih taksonomskih stopenj. Glede na to, da se vsi trije pojmi obravnavajo pri pouku geografije v osnovnošolskem izobraževanju, bi lahko pričakovali, da učenci in dijaki naštete pojme tudi poznajo. Šele ko učenec in dijak določen pojem usvoji, se lahko pri pouku konkretneje in podrobneje obravnavajo nanj vezane vsebine, saj brez osnovnega poznavanja terminologije ne moreta razumeti procesov. Pojmi diaspora, asimilacija, multikulturalizem in remigracija bi po našem mnenju sodili v obravnavo migracijskih tematik v srednji šoli, ko se lahko migracije obravnavajo nekoliko podrobneje, oziroma so se dijaki zmožni tudi podrobneje seznaniti s temi procesi.

Nenazadnje velja omeniti, da bi morala biti obravnavana terminologija v slovenskem šolstvu bolj in jasneje izpostavljena ter da bi morale biti teme, povezane z izseljenstvom, tudi drugače predstavljene. Nemalokrat namreč od dijakov in učencev slišimo, da se o izseljencih v šolah učijo, a vedno ene in iste stvari - koliko jih kje živi. Je takšno omenjanje statističnih podatkov res edini način, kako lahko naši učenci in dijaki spoznavajo teme izseljenstva? Verjetno bi lahko z vključevanjem bolj zanimivih vsebin, tudi zgodb, učenci in dijaki bolj slikovito spoznavali izseljenske tematike. Na takšen način bi bilo poznavanje terminologije boljše in trajnejše, obenem bi lahko s takšnimi metodami bolje razumeli tudi sodobne migracijske procese. 


\section{Viri in literatura}

An overview of international migration. 2014. International Organization for Migration (IOM), 396 str. URL: http://publications.iom.int/bookstore/free/WMR_2003.pdf (Citirano 31. 8. 2014).

Castles, S., Miller, M. J., 1998. The age of migration: international population movements in the modern world. London, MacMillan, 360 str.

Geografski atlas Slovenije. 1998. Ljubljana, DZS, 360 str.

Ilc Klun, M., 2014. Slovensko izseljenstvo in diaspora v procesu geografskega izobraževanja. Raziskava na slovenskih osnovnih in srednjih šolah.

International convention on the protection of the rights of all migrant workers and members of their families. 1990. United Nations, General Assembly. URL: http://www. un.org/documents/ga/res/45/a45r158.htm (Citirano 25. 8. 2014).

International migration law: glossary on migration. 2004. URL: http://publications.iom. int/bookstore/free/IML_1_EN.pdf (Citirano 30. 8. 2014).

Klinar, P., 1976. Mednarodne migracije (Sociološki vidiki mednarodnih migracij v luči odnosov med imigrantsko družbo in imigrantskimi skupnostmi). Maribor, Založba Obzorja, 306 str.

Komac, M., Medvešek, M., 2005. Percepcije slovenske integracijske politike. Zaključno poročilo. Ljubljana, Inštitut za narodnostna vprašanja, 801 str. URL: http://ec.europa. eu/ewsi/UDRW/images/items/docl_15454_577910389.pdf (Citirano 25. 8. 2014).

Kovač, B., 2003. Globalizacija, migracijski tokovi in ekonomski razvoj na obrobju slovenskih migracijskih dilem. V: Pajnik, M., Zavratnik Zimic, S. (ur.). Migracije - globalizacija - Evropska unija. Ljubljana, Mirovni inštitut in Inštitut za sodobne družbene in politične študije, 346 str.

Lukšič-Hacin, M., 1999. Multikulturalizem in migracije. Ljubljana, Založba ZRC, 269 str.

Milharčič-Hladnik, M., 2009. Multikulturalizem v kontekstu migracij. Knjižnica: revija za področje bibliotekarstva in informacijske znanosti, 53, 1-2, str. 143-151.

Popit, S., 2011. Geografija 1. Učbenik za 1. letnik gimnazije. Ljubljana, DZS, 190 str.

Population density. 2014. URL: http://data.worldbank.org/indicator/EN.POP.DNST (Citirano 17. 9. 2014).

Senegačnik, J., 2012. Geografija Slovenije. Učbenik za 9. razred osnovne šole. Ljubljana, Modrijan, 142 str.

Senegačnik, J., Drobnjak, B., Otič, M., 2007. Živim v Sloveniji. Geografija za 9. razred osnovne šole. Ljubljana, Modrijan, 150 str.

Senegačnik, J., Drobnjak, B., 2010. Obča geografija za 1. letnik gimnazij. Ljubljana, Modrijan, 192 str.

Slovenci po svetu. 2014. Urad vlade Republike Slovenije za Slovence po svetu in v zamejstvu. URL: http://www.uszs.gov.si/si/delovna_podrocja/slovenci_po_svetu (Citirano 28. 8. 2014).

Slovenci v zamejstvu. 2014. Urad vlade Republike Slovenije za Slovence po svetu in v zamejstvu. URL: http://www.uszs.gov.si/si/delovna_podrocja/slovenci_v_zamejstvu (Citirano 24. 8. 2014). 
Stark, O., 1991. The migration of labour. Cambridge, Oxford, Basil Blackwell, 396 str. Verdev, H., 2011. Raziskujem Slovenijo 9. Učbenik za geografijo v 9. razredu osnovne šole. Ljubljana, Rokus Klett, 95 str.

\section{THEORETICAL ASPECTS OF EMIGRATION AND KNOWLEDGE OF EMIGRATION TERMINOLOGY AMONG SLOVENIAN PUPILS}

\section{Summary}

Historical and theoretical overview of the study of migration shows that there are considerable differences between theoretical approaches of studying and the perception of migrations. Although some theories emphasize economic factors and other the role of individuals or groups, the migration is a complex social phenomenon that requires a comprehensive approach. When analyzing individual migration, we must pay attention to all factors that affect the migration flow - so we must be interested in reasons why individuals or group of people decide to leave certain area and which are the causes that led those individuals or groups to another area.

Besides the fact that migration is seen as a broad and complex phenomenon, it is also important to know how well are the contents related to migration represented in Slovenian educational system. Issues related to migration should become an important topic in Slovenian educational system, not only because of modern migration flows in 21 st century but also because of integration of the Slovenian nation in the migration processes. In this segment, we should also rise the following questions: is the knowledge of migration terminology among pupils necessary and, why and how much should pupils know about certain terminology?

The survey shows that almost $63 \%$ of pupils know the term emigrant, while the percentage of correct explanation of the other two terms (migrant worker and national minority of neighbouring country) is much lower. We can highlight the lack of knowledge of the term migrant worker $^{3}$ as almost $54 \%$ of pupils are not familiar with it, although the review of geographical textbooks shows that the term migrant worker is present in educational process and that the description of the term appears together with the emigrant. So, what is the reason that pupils understand the term emigrant but they do not understand the term migrant worker? The answers could be that the contents related to emigration are more highlighted in educational process and the emigration can be the theme in different school subjects because of modern migration flows, while the term emigrant worker is expressed only when dealing with the topics

3 In Slovenian terminology, we use the word zdomec for migrant worker and it was also used in the survey. We might have better results of knowing the term migrant worker if we would use the term ekonomski migrant which is direct translation of migrant worker, but if we have Slovenian word for the term and if that word is used in school textbooks, we decided to use the term zdomec also in the survey. Some might set the question why the pupils do not understand the term migrant worker, but they understand the term emigrant. The answer to the question is because in Slovenian language we use the term $z$ domec, which you have to know if you want to explain the reason for migration of that person and give a definition of the term. 
related to temporary emigration of Slovenians (the 9th grade or primary school and 1 st, 3rd or 4th of high school).

The survey also shows that the pupils are not very familiar with the terms diaspora, assimilation, multiculturalism and remigration. The terms are neither part of objectives in geography school curricula, nor they are presented in geography textbooks. Therefore, the results of the survey are not surprising. Nevertheless, we should mention that among all of mentioned terms, the most well known concept is the term multiculturalism, probably due to its wider use in everyday life.

In our opinion, after finishing primary school, the pupils should be familiar with the terms emigrant, migrant worker and national minority of neighbouring country - they should know the terms and properly distinguish from each other. Knowing the basic terminology is necessary to achieve the learning objectives of higher taxonomic levels. Because all three terms are included in geography textbooks for primary schools, we should expect that the pupils know the terms well. Only when pupils acquire certain terminology, they are able to learn about more detailed contents related to the term. Without basic knowledge of terminology, pupils cannot understand the processes that are tied to a certain term. Terms such as diaspora, assimilation, multiculturalism and remigration should, by our opinion, be part of high school education, when students are able to learn about migration processes in more details.

We could conclude that the migration terminology should be expressed clearly in Slovenian textbooks and educational system and the topics related to emigration should be presented in other way. We can often hear the pupil's opinion that they learn about the emigration in schools always in the same way - how many Slovenian emigrants live outside Slovenia and where. Is this (mentioning the statistical data about Slovenian emigrants) really the only way to teach our students about emigration topics? In our opinion, it would be more interesting for pupils to include in teaching process about migrations more interesting topics, including emigration stories, that the understanding of migration terminology should be better and lasting. 